\title{
ASSESSMENT OF SERUM MAGNESIUM LEVEL IN CHRONIC RENAL FAILURE PATIENTS AND ITS CLINICAL SIGNIFICANCE AND CORRELATION WITH SODIUM, POTASSIUM AND CALCIUM
}

\author{
Ramgopal Ghritlahare ${ }^{1}$, Rajkumar Baranwal ${ }^{2}$ \\ ${ }^{1}$ Assistant Professor, Department of Medicine, Dr. Bhimrao Ambedkar Memorial Hospital, Raipur. \\ ${ }_{2}^{2}$ Postgraduate Resident, Department of Medicine, Dr. Bhimrao Ambedkar Memorial Hospital, Raipur.
}

\begin{abstract}
\section{BACKGROUND}

Electrolyte metabolism and its pathological alteration in relation to clinical features is subject of modern interest. There are four major cations in the body namely sodium, potassium, calcium and magnesium; first three cations have been extensively studied but studies concerning magnesium metabolism have lagged in words of Peter and Vanslyke [1931] ${ }^{9}$; so far no clinical significance has been attached to changes in magnesium metabolism due to the fact that Meltzer and Aner [1905] demonstrated that raising the blood magnesium gives rise to coma and that Kruse et al [1932] ${ }^{6}$ produced a form of tetany by inducing magnesium deficiency. It is possible that magnesium imbalance may be playing a greater role in clinical medicine than has been suspected heretofore. There are conflicting report in literature concerning serum magnesium in chronic renal diseases, Huschfelder and Haury [1934], Marti et al [1952] and Boutwell [1961] found hypomagnesaemia, while Predhan et al [1961] and numerous others works found definite hypermagnesaemia in chronic renal disease. Pathophysiology of certain symptoms in uraemia remains a mystery. It is generally regarded that end products of metabolism accumulate lead to depression of central nervous system. If in cases of renal diseases without uraemia, when magnesium is given to the patient, depression of central nervous system is produced, Hirschfelder $1934,{ }^{4}$ which suggest that increase in serum magnesium may explain the nervous depression in uraemia patients. Engbaek [1952] and Cantarow [1959] stated that rise in serum magnesium is associated with the depression of central nervous system. These workers and others who found hypermagnesaemia in chronic renal disease found relationship with central nervous system depression in renal uraemia.

The aims of this study are,

1. To find out the co-relationship of serum magnesium and blood urea in patients suffering from various types of kidney diseases.

2. To correlate the serum magnesium level with the depression of central nervous system if possible.

3. To find out the prognostic significance of serum magnesium level in cases wherever possible.

4. To find out the co-relationship to serum magnesium and serum potassium, serum calcium and serum sodium.
\end{abstract}

\section{MATERIALS AND METHODS}

The present study comprised of 35 cases of chronic renal failure, 20 healthy control cases.

Criteria for Selection of Cases - Diagnosis of chronic renal failure was established by measuring raised blood urea, nitrogen (BUN) and serum creatinine with clinical sign and symptoms of renal failure. Out of this 35 cases, 8 patients underwent haemodialysis procedures and followed the patients.

Method for Estimation of Serum Electrolyte and Blood Urea and Serum Creatinine and other Investigations-

1. Serum magnesium estimation was done by modified titan - yellow method as cited by Hawk et al.

2. Serum sodium and serum potassium estimation was done by flame photometry using E.E.L. Flame Photometry. Normal value for serum sodium - Range 137 - $148 \mathrm{mEq} / \mathrm{L}$ and for Serum Potassium - Range 3.6 - $5 \mathrm{mEq} / \mathrm{L}$.

3. Blood urea estimation was done by King and Wooton (1964) and using serum creatinine estimation was done by Jaffe reaction as detailed by Folin and Wu modified by Bonson and Tausky.

\section{RESULT}

It has been observed in the present study of 35 cases of CRF, the mean value of serum magnesium level was $4.11 \%$ (Range 2.97 $7.18 \mathrm{mg} \%$ ), which is more than normal $1.94 \mathrm{mg} \%$. All the 35 cases of CRF had high blood urea level i.e. mean $137.54 \mathrm{mg} \%$ and high creatinine value i.e. mean $5.6 \mathrm{mg} \%$, so there was positive correlation between serum magnesium level and blood urea and serum creatinine level. This serum potassium level was mean $5.1 \mathrm{mEq} / \mathrm{L}$ and serum calcium level was mean $9.37 \mathrm{mEq} / \mathrm{L}$, so there was a positive correlation between serum potassium and serum magnesium level and negative correlation between serum magnesium and serum calcium level. Regarding the effect of hypermagnesaemia, it is universally accepted that magnesium is central nervous system depressant. However, the relationship between serum magnesium level and various grades of central nervous system depression is not established. In present series 35 cases of chronic renal disease hypermagnesaemia was present in 34 (97.14\%) cases, but only 12 cases (34.28\%) had central nervous system depression of various grades; out of this 3 cases had coma with serum magnesium level of $5.61 \mathrm{mg} \%$.

Role of Dialysis - Dialysis in form reduces serum magnesium level as observed in this study. Patient with high serum magnesium level with CNS depression improved with dialysis. In cases of CRF mean serum magnesium level was $4.25 \pm 0.95 \mathrm{mg} \%$, which become $3.41 \pm 0.55 \mathrm{mg} \%$ after haemodialysis with $0.86 \pm 0.48 \mathrm{mg} \%$ fall in serum magnesium level. 


\section{CONCLUSION}

1. There was definite positive correlation between serum magnesium and blood urea level.

2. There is positive correlation between magnesium level and serum potassium level.

3. There is positive correlation between serum magnesium and serum creatinine level.

4. There is negative correlation between serum magnesium and serum calcium level.

5. There is no correlation found between serum magnesium and serum creatinine level.

6. The cases having central nervous system depression had high serum magnesium level.

7. There is definite role of haemodialysis in lowering the serum magnesium level and clinical improvement of patient.

8. There is negative correlation between serum magnesium and urine output level.

\section{KEYWORDS}

Chronic Renal Failure, Magnesium, Sodium, Potassium Calcium, Haemodialysis.

HOW TO CITE THIS ARTICLE: Ghritlahare R, Baranwal R. Assessment of serum magnesium level in chronic renal failure patients and its clinical significance and correlation with sodium, potassium and calcium. J. Evolution Med. Dent. Sci. 2016;5(90):6733-6739, DOI: $10.14260 /$ jemds/2016/1521

\section{BACKGROUND}

Electrolyte metabolism and its pathological alteration in relation to clinical features is subject of modern interest. There are four major cations in the body namely sodium, potassium, calcium and magnesium. First three cations have been extensively studied, but studies concerning magnesium metabolism have lagged in words of Peter and Vanslyke [1931]; so far no clinical significance has been attached to changes in magnesium metabolism due to the fact that Meltzer and Aner [1905] demonstrated that raising the blood magnesium gives rise to coma and that Kruse et al [1932] produced a form of tetany by inducing magnesium deficiency. It is possible that magnesium imbalance may be playing a greater role in clinical medicine than has been suspected heretofore.

Serum magnesium is of particular interest in kidney diseases, eclampsia, delirium tremens and myocardial infarction.

There are conflicting report in literature concerning serum magnesium in chronic renal diseases. Huschfelder and Haury [1934],3 Marti et al [1952] ${ }^{7}$ and Boutwell [1961] found hypomagnesaemia, while Predhan et al [1964]10 and numerous others works found definite hypermagnesaemia in chronic renal disease.

Pathophysiology of certain symptoms in uraemia remains a mystery; it is generally regarded that end products of metabolism accumulate and lead to depression of central nervous system and if in cases of renal diseases without uraemia, when magnesium is given to the patient, depression of central nervous system is produced, Hirschfelder 1934, ${ }^{4}$ which suggest that increase in serum magnesium may explain the nervous depression in uraemia patients. Engbaek [1952] ${ }^{2}$ and Cantarow [1959] stated that rise in serum magnesium is associated with the depression of central nervous system. These workers and others who found hypermagnesaemia in chronic renal disease, found relationship with central nervous system depression in renal uraemia.

Financial or Other, Competing Interest: None.

Submission 21-10-2016, Peer Review 02-11-2016,

Acceptance 04-11-2016, Published 10-11-2016.

Corresponding Author:

Dr. Ramgopal Ghritlahare,

\#g-4, Gomti Vihar Amlidih,

Raipur.

E-mail: rgghritlahare03@gmail.com

DOI: $10.14260 /$ jemds/2016/1521

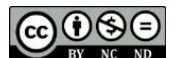

\section{Aims and Objectives}

1. To find out the co-relationship of serum magnesium and blood urea in patients suffering from various types of kidney diseases.

2. To correlate the serum magnesium level with the depression of central nervous system if possible.

3. To find out the prognostic significance of serum magnesium level in cases wherever possible.

4. To find out the co-relationship to serum magnesium, serum potassium, serum calcium and serum sodium.

\section{MATERIALS AND METHODS}

The present study comprised of 35 cases of chronic renal failure with 20 healthy control cases.

Criteria for Selection of Cases: Diagnosis of chronic renal failure was established by measuring raised Blood Urea Nitrogen (BUN) and serum creatinine with clinical sign and symptoms of renal failure. Out of this 35 cases, 8 patients underwent haemodialysis procedures and followed the patients.

Method for Estimation of Serum Electrolyte and Blood Urea and Serum Creatinine and other Investigations

1. Serum magnesium estimation was done by modified titan-yellow method as cited by Hawk et al.

2. Serum sodium and serum potassium estimation was done by flame photometry using E.E.L. Flame Photometry. Normal value for serum sodium - Range 137 - $148 \mathrm{mEq} / \mathrm{L}$ and for serum potassium - Range 3.6 - $5 \mathrm{mEq} / \mathrm{L}$.

3. Blood urea estimation was done by King and Wooton (1964) using and serum creatinine estimation was done by Jaffe reaction as detailed by Folin and Wu modified by Bonson and Tausky.

\section{Observation}

35 patients suffering from chronic kidney disease were selected to study the serum magnesium level; 20 normal individuals of various age groups were selected as controls.

\begin{tabular}{|c|c|c|c|}
\hline $\begin{array}{c}\text { Sl. } \\
\text { No. }\end{array}$ & $\begin{array}{c}\text { Age in } \\
\text { Yrs. }\end{array}$ & Sex & $\begin{array}{c}\text { S. Magnesium } \\
\text { in mg\% }\end{array}$ \\
\hline 1 & 25 & M & 1.75 \\
\hline 2 & 20 & M & 1.66 \\
\hline 3 & 35 & M & 2.62 \\
\hline 4 & 23 & F & 2.15 \\
\hline 5 & 50 & F & 1.66 \\
\hline 6 & 36 & F & 1.54 \\
\hline
\end{tabular}




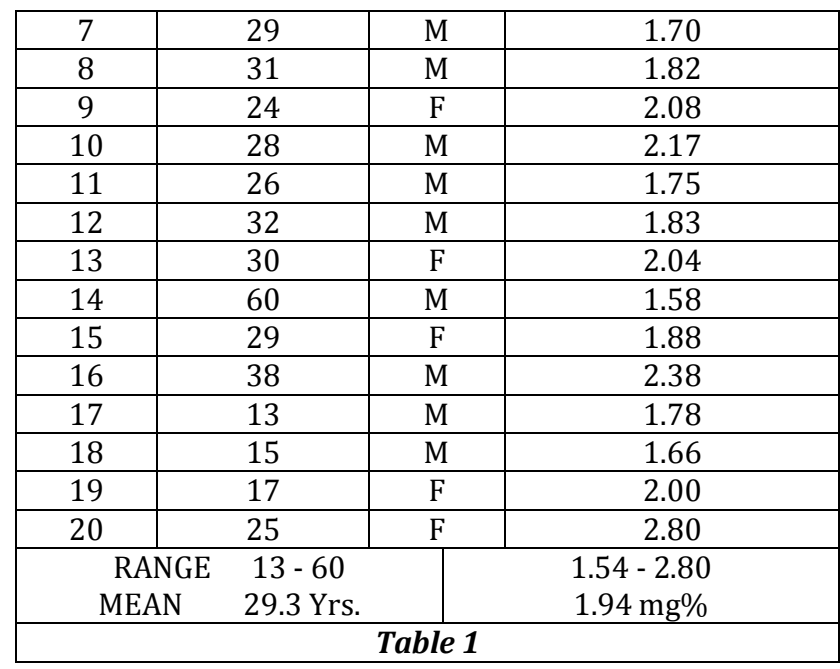

Above table shows that out of 35 cases of CRF, 12 cases (34.28\%) had CNS depression. Among the 12 cases, 9 had confusion and 3 had coma. Their mean S. magnesium level was $3.96 \pm .57 \mathrm{mg} \%$ and $5.61 \pm 1.02 \mathrm{mg} \%$ respectively.

\begin{tabular}{|c|c|c|c|}
\hline Group & $\begin{array}{c}\text { Pulse } \\
\text { Rate }\end{array}$ & $\begin{array}{c}\text { No. of } \\
\text { Cases }\end{array}$ & $\begin{array}{c}\text { S. } \mathbf{~ m g} \\
\text { in } \mathbf{~ m g \%}\end{array}$ \\
\hline $1(4)$ & $<60$ & $4(11.42 \%)$ & $5.1 \pm 1.93$ \\
\hline $2(17)$ & $60-100$ & $17(48.57 \%)$ & $4.16 \pm 0.72$ \\
\hline $3(14)$ & $>100$ & $14(40 \%)$ & $3.53 \pm 0.56$ \\
\hline \multicolumn{4}{|c|}{ Table 4. Showing Serum Magnesium } \\
Level with Pulse Rate in Cases of CRF \\
\hline
\end{tabular}

Above table showing serum magnesium level in comparison to pulse rate, which shows negative corelationship between serum magnesium level and pulse rate of the patient.

\begin{tabular}{|c|c|c|}
\hline Sl. No. & No. of Cases & Symptoms \\
\hline 1 & 21 & Fever \\
\hline 2 & 6 & Haematuria \\
\hline 3 & 18 & Dysuria \\
\hline 4 & 22 & Vomiting \\
\hline 5 & 32 & Oedema \\
\hline 6 & 9 & Renal Colic \\
\hline 7 & 2 & Loose Motion \\
\hline 8 & 15 & Oliguria \\
\hline 9 & 9 & Confusion \\
\hline 10 & 3 & Coma \\
\hline Table 2. Showing Main Symptoms in 35 Cases of CRF \\
\hline
\end{tabular}

Above table shows main symptoms in 35 cases of chronic renal failure patient.

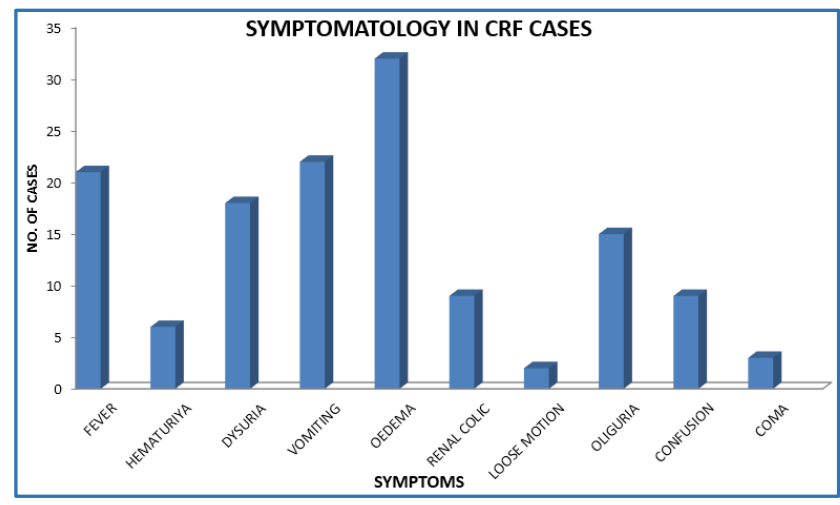

\begin{tabular}{|c|c|c|c|}
\hline $\begin{array}{l}\text { Sl. } \\
\text { No. }\end{array}$ & $\begin{array}{l}\text { Case } \\
\text { No. }\end{array}$ & $\begin{array}{l}\text { S. Magnesium } \\
\text { in } \mathrm{mg} \%\end{array}$ & $\begin{array}{l}\text { CNS } \\
\text { Status }\end{array}$ \\
\hline 1 & 1 & 4.17 & Confusion \\
\hline 2 & 5 & 4.19 & Confusion \\
\hline 3 & 9 & 4.19 & Confusion \\
\hline 4 & 10 & 5.14 & Coma \\
\hline 5 & 12 & 3.84 & Confusion \\
\hline 6 & 15 & 3.65 & Confusion \\
\hline 7 & 17 & 3.39 & Confusion \\
\hline 8 & 18 & 3.7 & Confusion \\
\hline 9 & 28 & 3.9 & Confusion \\
\hline 10 & 30 & 7.04 & Coma \\
\hline 11 & 33 & 5.65 & Confusion \\
\hline 12 & 35 & 7.18 & Coma \\
\hline & \multicolumn{3}{|c|}{$\begin{array}{lr}\text { RANGE } & 3.39-7.18 \\
\text { MEAN } & 4.83 \pm 1.44\end{array}$} \\
\hline
\end{tabular}

\begin{tabular}{|c|c|c|c|}
\hline Group & $\begin{array}{c}\text { Urine Output } \\
\text { in mL/24 hrs. }\end{array}$ & $\begin{array}{c}\text { No. of } \\
\text { Cases }\end{array}$ & $\begin{array}{c}\text { S. mg } \\
\text { in } \mathbf{~ m g \%}\end{array}$ \\
\hline 1 & $>1000$ & 7 & $3.12 \pm 0.15$ \\
\hline 2 & $600-1000$ & 11 & $3.16 \pm 0.23$ \\
\hline 3 & $400-600$ & 9 & $4.19 \pm 0.29$ \\
\hline 4 & $100-400$ & 4 & $4.83 \pm 0.31$ \\
\hline 5 & $<100$ & 4 & $6.22 \pm 0.86$ \\
\hline \multicolumn{3}{|c|}{ Table 5. Showing Serum Magnesium Level } \\
with Urine Output in Cases of CRF \\
\hline
\end{tabular}

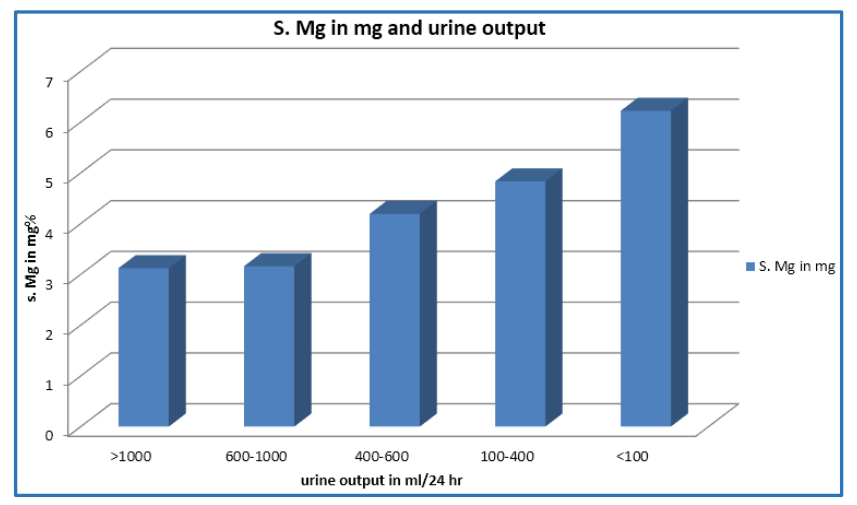




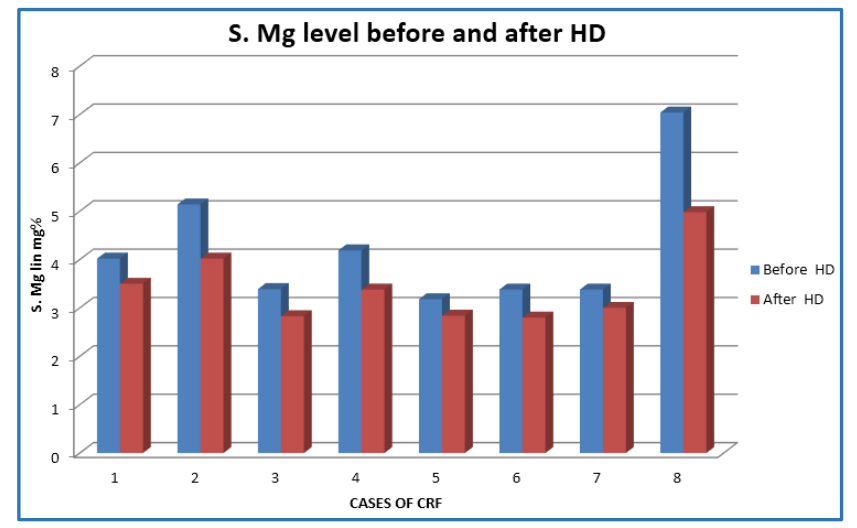

Above table shows serum magnesium level in comparison to 24-hour urine output of the patients and there is negative co-relationship between serum magnesium level and 24-hour urine output.

\begin{tabular}{|c|c|c|c|c|}
\hline \multirow{2}{*}{$\begin{array}{l}\text { Sl. } \\
\text { No. }\end{array}$} & \multirow{2}{*}{$\begin{array}{l}\text { Case } \\
\text { No. }\end{array}$} & \multicolumn{2}{|c|}{ S. mg Level in $\mathrm{mg} \%$} & \multirow{2}{*}{$\begin{array}{c}\text { S. mg Difference } \\
\text { in } \mathbf{m g} \%\end{array}$} \\
\hline & & Before HD & After HD & \\
\hline 1 & 20 & 4.02 & 3.5 & 0.52 \\
\hline 2 & 10 & 5.14 & 4.02 & 1.12 \\
\hline 3 & 17 & 3.39 & 2.83 & 0.56 \\
\hline 4 & 14 & 4.19 & 3.38 & 0.56 \\
\hline 5 & 24 & 3.18 & 2.84 & 0.81 \\
\hline 6 & 12 & 3.38 & 2.80 & 0.34 \\
\hline 7 & 26 & 3.38 & 3.00 & 0.58 \\
\hline 8 & 30 & 7.04 & 4.98 & 2.06 \\
\hline & & $4.25 \pm 0.95$ & $3.41 \pm 0.55$ & $0.86 \pm 0.48$ \\
\hline
\end{tabular}

Above table shows serum magnesium level before and after haemodialysis and their mean serum magnesium level. There is significant fall in serum magnesium level after haemodialysis, i.e. $0.86 \pm 0.48 \mathrm{mg} \%$ and definite symptomatic improvement.

\begin{tabular}{|c|c|c|}
\hline Sl. No. & Serum Mg in $\mathbf{~ m o \% ~}$ & Blood Urea in $\mathbf{~ g \%}$ \\
\hline 1 & 2.97 & 60 \\
\hline 2 & 3.04 & 62 \\
\hline 3 & 3.07 & 68 \\
\hline 4 & 3.09 & 78 \\
\hline 5 & 3.18 & 84 \\
\hline 6 & 3.28 & 88 \\
\hline 7 & 3.38 & 96 \\
\hline 8 & 3.27 & 96 \\
\hline 9 & 3.39 & 98 \\
\hline 10 & 3.5 & 100 \\
\hline 11 & 3.63 & 104 \\
\hline 12 & 3.64 & 108 \\
\hline 13 & 3.65 & 114 \\
\hline 14 & 3.7 & 116 \\
\hline 15 & 3.74 & 124 \\
\hline 16 & 3.75 & 128 \\
\hline 17 & 3.84 & 133 \\
\hline 18 & 3.9 & 139 \\
\hline 19 & 3.85 & 144 \\
\hline 20 & 4.02 & 148 \\
\hline 21 & 4.08 & 154 \\
\hline 22 & 4.17 & 164 \\
\hline 23 & 4.19 & 168 \\
\hline 24 & 4.65 & 168 \\
\hline & & \\
\hline
\end{tabular}

\begin{tabular}{|c|c|c|}
\hline 25 & 4.19 & 170 \\
\hline 26 & 4.45 & 172 \\
\hline 27 & 4.52 & 174 \\
\hline 28 & 4.37 & 176 \\
\hline 29 & 4.48 & 182 \\
\hline 30 & 4.89 & 189 \\
\hline 31 & 5.14 & 191 \\
\hline 32 & 5.36 & 200 \\
\hline 33 & 5.56 & 212 \\
\hline 34 & 7.04 & 223 \\
\hline 35 & 7.18 & 240 \\
\hline Mean & 4.11 & 137.54 \\
\hline \multicolumn{2}{|c|}{ Table 7 } \\
\hline
\end{tabular}

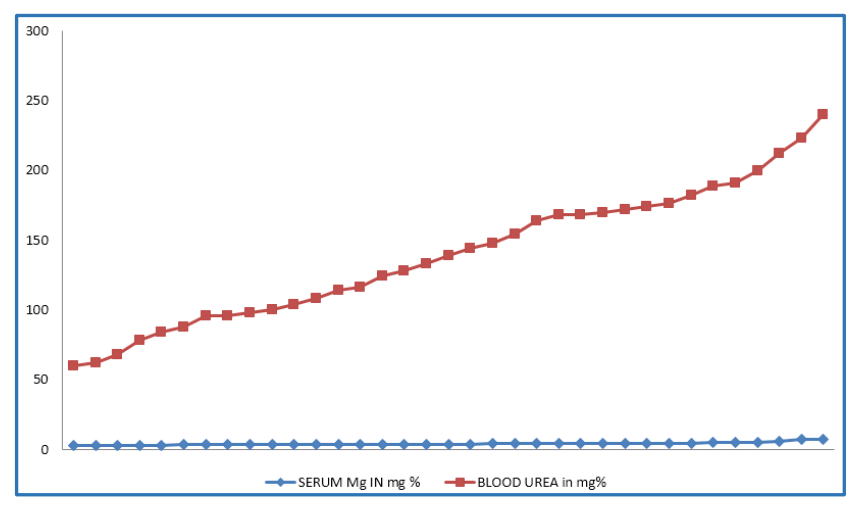

Table 7. Showing serum magnesium and blood urea level in chronic renal failure patients. This is showing significant positive co-relationship between serum magnesium level and blood urea level.

\begin{tabular}{|c|c|c|}
\hline Sl. No. & Serum Mg in $\mathrm{mg} \%$ & S. Creatinine in mg\% \\
\hline 1 & 2.97 & 3.4 \\
\hline 2 & 3.04 & 5.2 \\
\hline 3 & 3.07 & 4.1 \\
\hline 4 & 3.09 & 3.9 \\
\hline 5 & 3.18 & 5.2 \\
\hline 6 & 3.27 & 3.2 \\
\hline 7 & 3.28 & 5.3 \\
\hline 8 & 3.38 & 3.8 \\
\hline 9 & 3.39 & 5.3 \\
\hline 10 & 3.5 & 6 \\
\hline 11 & 3.63 & 4.2 \\
\hline 12 & 3.64 & 6.1 \\
\hline 13 & 3.65 & 5.6 \\
\hline 14 & 3.7 & 3.5 \\
\hline 15 & 3.74 & 5.1 \\
\hline 16 & 3.75 & 6.4 \\
\hline 17 & 3.84 & 5.8 \\
\hline 18 & 3.85 & 5.6 \\
\hline 19 & 3.9 & 5.9 \\
\hline 20 & 4.02 & 6.2 \\
\hline 21 & 4.08 & 5.2 \\
\hline 22 & 4.17 & 7.5 \\
\hline 23 & 4.19 & 8.1 \\
\hline 24 & 4.19 & 7.9 \\
\hline 25 & 4.37 & 7.5 \\
\hline 26 & 4.45 & 5.6 \\
\hline 27 & 4.48 & 5.3 \\
\hline 28 & 4.52 & 5.9 \\
\hline 29 & 4.65 & 5.6 \\
\hline 30 & 4.89 & 6.2 \\
\hline 31 & 5.14 & 7.7 \\
\hline
\end{tabular}




\begin{tabular}{|c|c|c|}
\hline 32 & 5.36 & 6.3 \\
\hline 33 & 5.56 & 9.8 \\
\hline 34 & 7.04 & 8.2 \\
\hline 35 & 7.18 & 9.2 \\
\hline Mean & $4.11 \pm 2.10$ & $5.6 \pm 4.2$ \\
\hline \multicolumn{2}{|r|}{ Table 8} \\
\hline
\end{tabular}

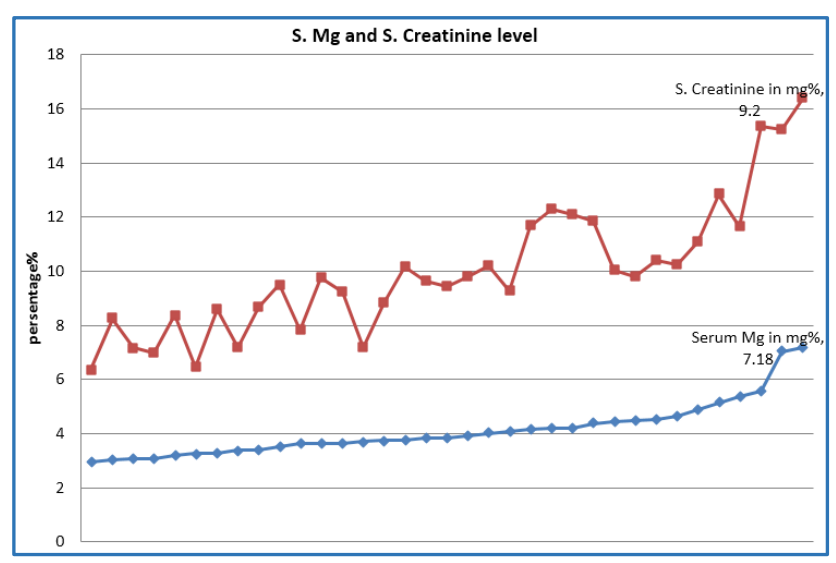

Above table showing in cases of chronic renal failure, mean serum magnesium level was $4.11 \pm 2.10 \mathrm{mg} \%$ and mean serum creatinine level was $5.6 \pm 4.2 \mathrm{mg} \%$, so this is showing positive co-relationship between serum magnesium and serum creatinine level.

\begin{tabular}{|c|c|c|}
\hline $\begin{array}{l}\text { Sl. } \\
\text { No. }\end{array}$ & $\begin{array}{l}\text { Serum Mg } \\
\text { in } \mathrm{mg} \%\end{array}$ & $\begin{array}{l}\text { Serum Potassium } \\
\text { Level in } \mathrm{mEq} / \mathrm{L}\end{array}$ \\
\hline 1 & 2.97 & 5.2 \\
\hline 2 & 3.04 & 4.1 \\
\hline 3 & 3.07 & 3.6 \\
\hline 4 & 3.09 & 3.5 \\
\hline 5 & 3.18 & 3.8 \\
\hline 6 & 3.27 & 4.5 \\
\hline 7 & 3.28 & 3.2 \\
\hline 8 & 3.38 & 3.8 \\
\hline 9 & 3.39 & 4.5 \\
\hline 10 & 3.5 & 4.1 \\
\hline 11 & 3.63 & 5.2 \\
\hline 12 & 3.64 & 5.2 \\
\hline 13 & 3.65 & 5.1 \\
\hline 14 & 3.7 & 4.1 \\
\hline 15 & 3.74 & 4.6 \\
\hline 16 & 3.75 & 3.9 \\
\hline 17 & 3.84 & 4.6 \\
\hline 18 & 3.85 & 5.6 \\
\hline 19 & 3.9 & 3.1 \\
\hline 20 & 4.02 & 3.8 \\
\hline 21 & 4.08 & 5.6 \\
\hline 22 & 4.17 & 5.7 \\
\hline 23 & 4.19 & 5.5 \\
\hline 24 & 4.19 & 6.6 \\
\hline 25 & 4.37 & 5.6 \\
\hline 26 & 4.45 & 5.8 \\
\hline 27 & 4.48 & 5.9 \\
\hline 28 & 4.52 & 4.6 \\
\hline 29 & 4.65 & 6.1 \\
\hline 30 & 4.89 & 6.5 \\
\hline 31 & 5.14 & 5.6 \\
\hline 32 & 5.36 & 6.55 \\
\hline 33 & 5.56 & 6.85 \\
\hline 34 & 7.04 & 7.05 \\
\hline 35 & 7.18 & 9.2 \\
\hline Mean & $4.11 \pm 2.10$ & $5.1 \pm 1.95$ \\
\hline
\end{tabular}

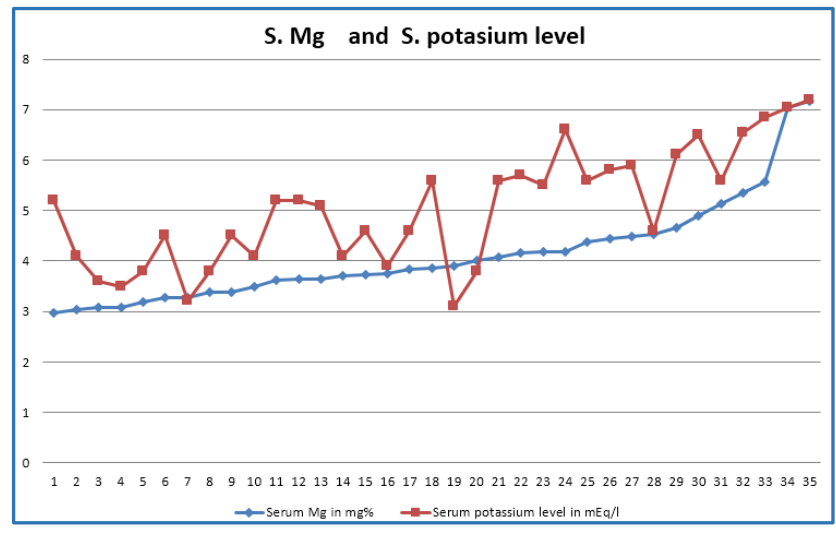

Above table showing serum magnesium and serum potassium level and this showing positive co-relationship between serum magnesium and serum potassium level.

\begin{tabular}{|c|c|c|}
\hline Sl. No. & Serum Mg in $\mathrm{mg} \%$ & Serum Calcium in $\mathrm{mEq} / \mathrm{L}$ \\
\hline 1 & 2.97 & 10.90 \\
\hline 2 & 3.04 & 10.85 \\
\hline 3 & 3.07 & 9.20 \\
\hline 4 & 3.09 & 10.10 \\
\hline 5 & 3.18 & 11.20 \\
\hline 6 & 3.27 & 10.80 \\
\hline 7 & 3.28 & 9.80 \\
\hline 8 & 3.38 & 9.60 \\
\hline 9 & 3.39 & 9.20 \\
\hline 10 & 3.5 & 9.00 \\
\hline 11 & 3.63 & 10.60 \\
\hline 12 & 3.64 & 9.50 \\
\hline 13 & 3.65 & 10.10 \\
\hline 14 & 3.7 & 10.10 \\
\hline 15 & 3.74 & 9.70 \\
\hline 16 & 3.75 & 10.20 \\
\hline 17 & 3.84 & 10.60 \\
\hline 18 & 3.85 & 9.80 \\
\hline 19 & 3.9 & 9.20 \\
\hline 20 & 4.02 & 8.90 \\
\hline 21 & 4.08 & 9.40 \\
\hline 22 & 4.17 & 8.50 \\
\hline 23 & 4.19 & 7.85 \\
\hline 24 & 4.19 & 8.90 \\
\hline 25 & 4.37 & 8.60 \\
\hline 26 & 4.45 & 8.40 \\
\hline 27 & 4.48 & 8.20 \\
\hline 28 & 4.52 & 8.60 \\
\hline 29 & 4.65 & 8.40 \\
\hline 30 & 4.89 & 8.20 \\
\hline 31 & 5.14 & 7.40 \\
\hline 32 & 5.36 & 8.60 \\
\hline 33 & 5.56 & 8.10 \\
\hline 34 & 7.04 & 7.50 \\
\hline 35 & 7.18 & 7.50 \\
\hline Mean & $4.11 \pm 2.10$ & $9.3 \pm 1.75$ \\
\hline \multicolumn{3}{|c|}{ Table 10} \\
\hline
\end{tabular}




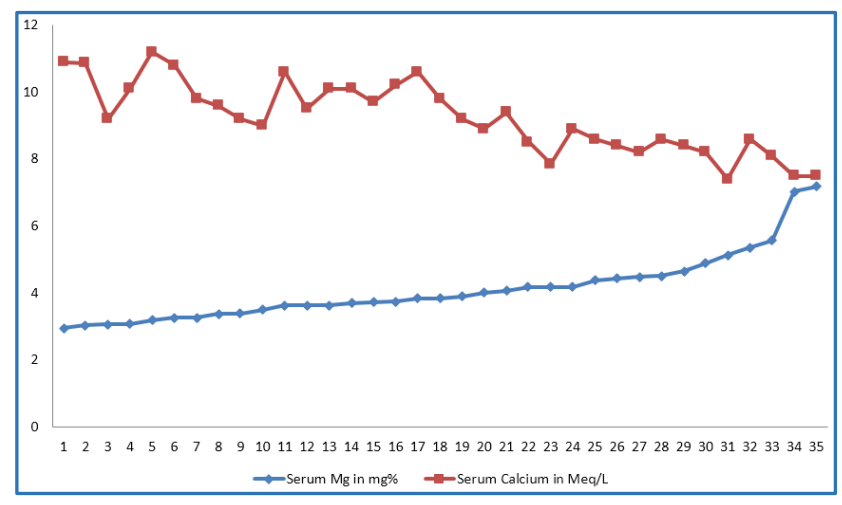

\begin{tabular}{|c|c|c|}
\hline $\begin{array}{c}\text { Above Table showing } \\
\text { Serum Magnesium and } \\
\text { Serum Calcium Level. This } \\
\text { showing Negative } \\
\text { Co-relationship between } \\
\text { Serum Magnesium } \\
\text { and Serum Calcium Level } \\
\text { Sl. No. }\end{array}$ & $\begin{array}{c}\text { S. } \\
\text { Magnesium } \\
\text { in } \mathbf{m g} \%\end{array}$ & $\begin{array}{c}\text { S. Sodium } \\
\text { in } \\
\mathrm{mEq} / \mathrm{L}\end{array}$ \\
\hline 1 & 2.97 & 148 \\
\hline 2 & 3.04 & 142 \\
\hline 3 & 3.07 & 122 \\
\hline 4 & 3.09 & 138 \\
\hline 5 & 3.18 & 132 \\
\hline 6 & 3.27 & 132 \\
\hline 7 & 3.28 & 132 \\
\hline 8 & 3.38 & 139 \\
\hline 9 & 3.39 & 136 \\
\hline 10 & 3.5 & 148 \\
\hline 11 & 3.63 & 148 \\
\hline 12 & 3.64 & 146 \\
\hline 13 & 3.65 & 146 \\
\hline 14 & 3.7 & 142 \\
\hline 15 & 3.74 & 156 \\
\hline 16 & 3.75 & 138 \\
\hline 17 & 3.84 & 146 \\
\hline 18 & 3.85 & 128 \\
\hline 19 & 3.9 & 138 \\
\hline 20 & 4.02 & 148 \\
\hline 21 & 4.08 & 148 \\
\hline 22 & 4.17 & 148 \\
\hline 23 & 4.19 & 156 \\
\hline 24 & 4.19 & 140 \\
\hline 25 & 4.37 & 140 \\
\hline 26 & 4.45 & 150 \\
\hline 27 & 4.48 & 152 \\
\hline 28 & 4.52 & 150 \\
\hline 29 & 4.65 & 140 \\
\hline 30 & 4.89 & 132 \\
\hline 31 & 5.14 & 156 \\
\hline 32 & 5.36 & 156 \\
\hline 33 & 5.56 & 152 \\
\hline 34 & 7.04 & 152 \\
\hline 35 & 7.18 & 142 \\
\hline Mean & $4.11 \pm 2.10$ & $143 \pm 17$ \\
\hline \multicolumn{3}{|c|}{ Table 11} \\
\hline
\end{tabular}

Above table showing serum magnesium level in comparison to serum sodium level. There is no co-relationship between serum magnesium level and serum sodium level.

\section{DISCUSSION}

It has been observed in the present study of 35 cases of CRF, the mean value of serum magnesium level was $4.11 \%$ (range $2.97-7.18 \mathrm{mg} \%$ ), which is more than normal $1.94 \mathrm{mg} \%$.

All the 35 cases of CRF had high blood urea level i.e. mean $137.54 \mathrm{mg} \%$ and high creatinine value i.e. mean $5.6 \mathrm{mg} \%$, so there was positive correlation between serum magnesium level and blood urea and serum creatinine level. This finding is similar to Smith et al 1958,12 Pradhan et al 196410 and Sharma et al 1990.11

In this serum potassium level was mean $5.1 \mathrm{mEq} / \mathrm{L}$ and serum calcium level was mean $9.37 \mathrm{mEq} / \mathrm{L}$, so there was a positive correlation between serum potassium and serum magnesium level and negative correlation between serum magnesium and serum calcium level. These findings are supported by work done by Smith and Hammarsten 1959.13

Regarding the effect of hypermagnesaemia, it is universally accepted that magnesium is central nervous system depressant. However, the relationship between serum magnesium level and various grades of central nervous system depression is not established.

Cantarow $1959^{1}$ stated that at $5 \mathrm{mg} \%$ of serum magnesium level sedation and mild hypnosis develops and at $15 \mathrm{mg} \%$ profound coma is produced. In present series of 35 cases of chronic renal disease hypermagnesaemia was present in 34 (97.14\%) cases, but only 12 cases $(34.28 \%)$ had central nervous system depression of various grades, out of this 3 cases had coma with serum magnesium level of $5.61 \mathrm{mg} \%$.

\section{Role of Dialysis}

Dialysis in form reduces serum magnesium level as observed in this study. Patient with high serum magnesium level with CNS depression improved with dialysis.

In cases of CRF mean serum magnesium level was $4.25 \pm$ $0.95 \mathrm{mg} \%$, which become $3.41 \pm 0.55 \mathrm{mg} \%$ after haemodialysis with $0.86 \pm 0.48 \mathrm{mg} \%$ fall in serum magnesium level.

Findings observed in dialysed cases in present study is similar to the finding of Jain and Singh et al 1969,4 Karim and James et al 19705 and Sharma et al 1990.11

\section{Summary and Conclusion}

1. There is definite positive correlation between serum magnesium and blood urea level.

2. There is positive correlation between magnesium level and serum potassium level.

3. There is positive correlation between serum magnesium and serum creatinine level.

4. There is negative correlation between serum magnesium and serum calcium level.

5. There is no correlation found between serum magnesium and serum creatinine level.

6. The cases having central nervous system depression had high serum magnesium level.

7. There is definite role of haemodialysis in lowering the serum magnesium level and clinical improvement of patient.

8. There is negative correlation between serum magnesium and urine output level. 


\section{REFERENCES}

1. Sharma, Singh. JAPI 1990;38(8):569-71.

2. Pradhan PK, Saxena BP, Gupta HC. Serum magnesium level in health and kidney diseases. J Indian MA 1964; 43:275-8.

3. Martin HE, Mehl J, Wertman M. Clinical studies of magnesium metabolism. Med Clinic North America 1952; 21:1157-71.

4. Hirschfelder AD. Effects of renal insufficiency upon plasma magnesium excretion after ingestion of magnesium sulphate. J Biol Chem 1934;104:647-53.

5. Meltzer SJ, Auer J. Am J Physiol 1905:80-85.

6. Smith WO, Hammarsten JF. Intracellular magnesium in delirium tremens and uraemia. Am J Med ScI 1959; 237(4):413-7.
7. Engbaek L. The pharmacological actions of magnesium ions with particular reference to the neuromuscular and the cardiovascular system. Pharmacol Rev 1952;4 (4):396-414.

8. Smith WO, Hammarsten JF. Serum magnesium in renal diseases. AMA Arch Int Med 1958;102(1):5-9.

9. Cantarow A. Diseases of metabolism. In: Duncan GG. edr. $4^{\text {th }}$ edn. Philadelphia, London: WB Saunders Co 1959. P. 245.

10. Mansouri K, Halsted JA, Gombos EA. Zinc, Copper, Magnesium and Calcium in dialyzed and nondialyzed Uremic patients. Arch Intern Med 1970;125(1):88-93.

11. Kruse HD, Orent ER, McCollum EV. Studies on Magnesium deficiency in animals. J Biol Chem 1932; 96:519-39. 